DOI: $10.1515 /$ rpp-2017-0049

$\mathrm{PhD}$ in Pedagogyical Sciences, Associate Professor, LIUDMYLA MATSIUK

Vasyl Stephanyk Precarpathian National University Address: 57 Shevchenko St., Ivano-Frankivsk, 76018, Ukraine

E-mail: plo4447@ukr.net

\title{
FUTURE TEACHERS' LEGAL TRAINING IN BELARUS AND KAZAKHSTAN
}

\begin{abstract}
The content of legal education of future primary school teachers which is adequate to the structural and functional model of teacher's professional readiness for increasing legal literacy of primary school pupils has been revealed and the main groups of competences, namely, normative and institutional, ideological and value-based, forecasting, procedural and functional as well as criteria and levels of readiness at the level of realizing certain actions during curricula and extracurricular activities and methods of diagnozing its effectiveness have been defined. The factors hampering innovations in professional activity of modern teachers have beenoutlined, in particular, socioeconomic factors and psychological barriers, personal anxiety, conformism, fear of one's own incompetence, low self-esteem, subjective-biased attitude to innovations, unwillingness to take independent decisions without appropriate recommendations and guidelines. The pedagogical conditions that contribute to forming future teachers'professional readiness for increasing legal literacy have been defined, namely, forming legal knowledge in the process of studying professional disciplines, improving the content of legal education by means of a special course, levelbased diagnostics of professional readiness, etc. The training process has been considered as a certain educational strategy, based on the principles of students' independent search and providing individualized and differentiated approaches to their training. It has been justified that professional training of future teachers for increasing legal literacy of primary shcool pupils is improved based on the influence of society due to adhereing to humanistic and democratic principles that significantly affect teachers' innovative activities and perform initiating and stimulating functions. The methodical system of forming students' knowledge, skills and developing their professional and personal qualities and abilities necessary for successful realization of professional legal activities has beenstudied. Comparative analysis of future teachers' legal training in higher education institutions of Ukraine, Belarus and Kazakhstan has been conducted.
\end{abstract} methods.

Keywords: future pedagogues, legal support, content, structure, forms, teaching

\section{INTRODUCTION}

Today, teacher education becomes an open system for perceiving and transferring innovative experience. Of great importance are joint educational projects of the leading universities in different countries, academic mobility of the students and the teachers, their creative communication through participation in international forums, conferences, symposiums. Therefore, studying foreign experience in organizing legal training of future teachers is relevant and timely. After all, reforming education in Ukraine initiates such training of teachers, which would not only reflect the specifics of their professional activities, but also optimally satisfy educational diversity. Based on this, there is an objective 
contradiction, generated by inconsistency between the content, forms and methods of traditional teacher training and social order in relation to their legal activities in a modern school. The analysis of mass actions of primary school teachers shows that in the modern school a clear and well-justified system of pupils' legal education has not been formedyet; theory and methodology of legal activitiesfor primary schoolpupilshas not been sufficiently developed taking into account the achievements of foreign experience, whereas practical teacher training in teacher education institutions is aimed at forming their didacticmethodical culture. In the context of training students for increasing legal literacyof primary school pupils in higher education institutions, the outlined aspect requires substantial improvement. Therefore, studying foreign experience in organizing legal training of future primary school teachers is important in terms of methods, techniques and means of its implementation.

\section{THE AIM OF THE STUDY}

The paper is aimed at analyzing and comparing the content, structure, forms and methods of future teachers' legal support in higher education institutions of Ukraine, Belarus and Kazakhstan.

\section{THEORETICAL FRAMEWORK AND RESEARCH METHODS}

The analysis of scientific literature has shown that the problem of future teachers' legal training in Ukraine has been considered by M. Horodyskyi, Yu. Kalynovskyi, M. Podberezkyi, T. Poshtar, V. Salnikov, O. Skakun, O. Solomatin, M. Tsymbaliuk et al. In Belarus, pedagogical aspects of forming legal culture of pupils and students have been studied by S. Bolonina, O. Borscheva, A. Dyzhova (2012), S. Ermolich (2013), I. Tcarik (2008). In Kazakhstan, legal training of future teachers has been analyzed by M. Malibekova, B. Mukushev (2009), S. Mukushev (2009), G. Utiupova (2017).

In order to study the problem of future teachers' legal training in Belarus and Kazakhstan, such methods as generalization and systematization have been used. In addition, we have applied comparative analysis.

\section{RESULTS}

Higher teacher education is aimed at preparing teachers who possess not only profound subject-specific knowledge, but also high legal culture and are able to creatively solve complex economic and social issues (Ziaziun, 1997).

Currently, professional training of teachers involves their mastering subject-specific knowledge and developing theoretical, methodological and psycho-pedagogical readiness for educational work, but, unfortunately, does not provide for forming their readiness using legal knowledge in their professional activities.

Theoretical and experimental researches show that in order to form a real picture of the state of the education process in a modern primary school, it is necessary to focus students' attention not only on the didactics of primary school, but also the integrity of its education process, during their first year at university education. Therefore, in our study we have attempted to provide teaching practice, which future teachers must undergo, not only with instructive, but also methodological materials. Such peculiar complexes simultaneously included methods for diagnosing the level of children'sawareness of legal information, as well as schemes for analyzing the education process. This has contributed to forming the students' pedagogical thinking.

While conducting our study, such disciplines as Fundamentals of Law, Fundamentals of Constitutional Law, History of Ukraine, History of Pedagogy, Pedagogy, Ukrainian and Foreign Culture, Ethnopedagogy, Fundamentals of Pedagogical Mastery, a special course on Training Teachers for Legal Work in Primary Schools have acquired the 
expected professional orientation. Simultaneously, the applied orientation of those sections and themes that were related to legal issues in the field of childhood and motherhood at different levels of the hierarchy, namely, from family to transnational ones, has enhanced. While studying professional disciplines, organizational forms and certain methods of working with the students, we were guided by the real education process, taking into account the conditions under which it is taking place today, as well as those social changes that affect its meaning and purposefulness. Thus, the requirements for the content and the organization of future teachers' training for increasing primary school pupils' legal literacy have been initiated by the patterns of modern professional training of teachers for working with primary school pupils.

These requirements functioned as certain principles: an interdisciplinary approach to training future teachers for increasing primary school pupils' legal literacy; professional orientation toward organizing legal education at school, namely, studying and implementing the basic institutional and legal documents that define the system of views and knowledge aimed at educating adequate value-based legal orientations; differential and systemic training. Simultaneously, it has allowed distinguishing between the common and different features in the content of fundamental values, intensified understanding culture of the ethnic group, the nation, the state and motivated each student toward studying those disciplines that have not been mastered yet; a didactic resonance, which has ensured choosing methods of teaching and learning and contributed to optimizing the process of professional training.

The outlined principles were complementary and created a relative integrity, which positively influenced the education process at a university in general. The defining principle of training future teachers for increasing legal literacy of primary school pupils, we have considered the interdisciplinary approach, which was implemented in interpersonal relationships. In our view, this is the integration of training future teachers for increasing legal literacy of primary school pupilsby means of professional disciplines, as well as a special course as a corrective and generalizing link of this system and teaching placement.

By creating such a scheme for integrating disciplines, we have used a psychological proof of the unity of figurative and conceptual components of thinking and associativity of the links between them based on the domain (Eremkin, 1984). Simultaneously, we have attempted to intensify the process of training future teachers not only in this aspect, but also in general. In teaching the outlined disciplines, the main attention has beenpaid to interdisciplinary planning, eliminating duplication of the main categories and facts, organizing rational lessons using unconventional approaches. Based on the outlined theoretical positions, the basis of our integration has become deductive-inductive logic for deploying the content of disciplines: from general - to partial, from partial - to general at the highest level of abstraction.

The course on Pedagogy we have considered as the main one in the system of professionaldisciplines. It was aimed at mastering the foundations of modern pedagogy and forming pedagogical knowledge, skills and abilities.

Rather important is the course on History of Pedagogy, in particular, its sections and topics that have shown determinism of the content of pedagogical ideas at the level of socio-cultural development. Thus, we have proved objectivity of the reasons, why K. Venttcel's declaration was never approved in the Russian Empire in the late 19th- the early 20th century. Using the principle of determinism, we have revealed authenticity of S. Rusova's judgments that, in order to become a nation, Ukrainian people need much time (Venttcel, 1918). 
It should be noted that we have dedicated a special place to the course on Fundamentals of Pedagogical Mastery. Considerable attention has been paid to training the students for modeling pedagogical situations, developing necessary skills for communicating with their pupils, solving dilemmas and problematic tasks.

We have focused our attention on studying the course on Methodology of Educational Work, since this discipline is a continuation of the section of the course on Pedagogy. Its aim is to expand and deepen the knowledge and skills of future teachers in terms of theory and practice of the education process, to form readiness for solving specific problems in educational activities.

The main directions of establishing intersubject relations, we have considered, in particular, the following: enriching the content of professional readiness by theoretical materials of professionaldisciplines; systematizing and improving necessary skills and abilities based on methodical disciplines. In the context of legal education, The main sources have become the courses on Fundamentals of Law, Fundamentals of Constitutional Law, History of Ukraine, Ukrainian Studies, Pedagogy, Ukrainian and Foreign Culture, etc.

Alsowe have practiced the consistent study of professional disciplines based on the patterns of teaching theories in a higher education institution by S. Arkhangelskii, including studyingdisciplines propaedeutically, forming the system of subject-specific knowledge, concepts, definitions, principles, established within the disciplines; studying disciplines algorithmically taking into account relevant recommendations using methods and tools, formulating certain norms and rules; studying individual sectiones of disciplines heuristicallyand organizing students'independent work by methods of analytical and synthetic activity; solving problematic pedagogical tasks with the elements of scientific search and modeling the elements of the education process (Arkhangelskii, 1980).

By structuring the mentioned disciplines, we intended to take into account their leading concepts, ideas, patterns and opportunitiesin order to rationally combine theoretical and practical material for further deducting the integrative connections, which should be adjusted between the adjacent disciplines.

Thus, we aimed to encourage the students to reconsider therelevamt information during seminars and laboratory classes in order to transfer it to children. Systematization and generalization of the acquired knowledge has been practiced based on the final themes of sections of each discipline.

By structuring the educational material we aimed tooutline in each discipline certain topics and define their basic concepts. They included parametric features of the education process with primary school pupils (development, upbringing, learning, education, its goals and objectives); the main components of the education process (views, knowledge, skills, abilities, beliefs, worldview); the principles of the education process organization and management in primary schools.

By restructuring individual topics and rethinking their thematic blocks, we have ensured a significant improvement in the content and structure of specific methods of preschool and primary education, since it was objectively impossible to duplicate general pedagogical information and the students could immediately model fragments of different types of activities with children.

Consequently, depending on the functioning of integration and transformation processes and the structure of each discipline, the corresponding branch of knowledge has changed in the context of one or another methodology.

For our study, it was important to analyze foreign experience in organizing legal training of future teachers, in particular, in the Republic of Belarus and Kazakhstan. 
We have found out that the system of legal education under the conditions of higher education institutions of Belarus provides for:

1) diagnozing the initial level of legal culture formation;

2) determining the aim and specifying legal education objectives in the education process.

3) defining the content of legal education, taking into account pedagogical specialties and the level of students' legal culture formation;

4) selecting interactive methods and optimal forms of legal education organization;

5 ) implementing the process of forming and developing legal culture.

6) analysing and evaluatingthe results of pedagogical activities (Ermolich, 2013).

At the Belarusian State Pedagogical University named after Maxim Tank, the issues of legal education are solved with the use of the following methods and forms of working with the students: a conversation;a persuasion; a suggestion; a case study; brainstorming; a videoproduction review; a fair of social legal projects; a legal workshop; intellectual, business and role games; legal scenario-based tasks, the academy of legal knowledge, an auction of legal ideas, a round table, the legal Olympiad, a social legal dialogue, a debate, a discussion, collage making, newspaper creating, a legal marathon, a press conference, legal lectures, a legal laboratory, thematic information sessions on legal, socio-political topics, organization of thematic book exhibitions, social actions organization, meetings with prominent state and public figures in the legal sphere, etc. (Ermolich, 2013).

The innovative form in legal training is the author's project, titled "Student Mentoring", which is realized in the process of teaching Socio-Pedagogical Prevention of Offenses at the Faculty of Social and Pedagogical Technologies of the Belarusian State Pedagogical University named after Maxim Tank, in the context of which fourth-year students provide junior students with legal counceling, organize social patronage over schoolchildren, who need legal training in order to prevent delinquent behavior (Ermolich, 2013).

At the Belarusian State Pedagogical University named after Maxim Tank, legal training of future teachers is enhanced by improving legal culture of teaching staff in higher education institutions under the conditions of an unsteady legal space, involving outstanding law specialists, functioning of the legal space of the faculties in higher education institutions, tutors' activities directed at forming and developing their legal culture, using interactive methods and technologies, specificity of strategies for forming legal culture, improving methodological support, using integrated and differentiated approaches to legal education of future teachers, focus on the output level of legal culture formation, improving the process management and control (Ermolich, 2013; Tcarik, 2008).

In accordance with the decree of the President of the Republic of Kazakhstan dated February 1, 2010, No 922 "Strategic Plan for Development of the Republic of Kazakhstan up to 2020", it has been concluded to integrate education in Kazakhstan with the world community, to improve quality of higher education that must meet the international standards. In this regard, the education system in Kazakhstan is undergoing crucial and optimal transformations.

In addition to teaching Fundamentals of Law, future teachers' legal educationinthe Semey State Pedagogical Institute in the Republic of Kazakhstan is aimed at studying such optional courses as Fundamentals of the State Legislation of the Republic of Kazakhstan, Legal Documents for Implementing the Education Policy in the Republic of Kazakhstan, which reflects the issues of education in the context of state and legal, criminal and legal, civil aspects (Mukushev, 2009). 
The teachers actively participate in teaching and industrial placements, analyze the lessons and extracurricular activities conducted by the students. During the department meetings and the final conferences of pedagogy departments they regularly discuss topical problems of school courses, their teaching methodology (Mukushev, Malibekova \& Mukushev 2009).

In the system of teachers' professional training, the role of optionale courses and special seminars aimed at forming the students' ability to implement legal education, the knowledge of the legal status of juveniles and methods for preventing offenses is significantly growing. Topicalissues of the state and the law, the history of legal ideas, the legal status of teachers are studied in the block of those disciplines belonging to the category of optional courses and special seminars. It is also important to emphasize the educational and developing function of coursework and graduation papers, the topics of which are related to legal education and legal consciousness of the students (Mukushev, 2009).

\section{CONCLUSIONS}

Comparative analysis on the content of future teachers' legal training in Ukraine, Belarus and Kazakhstan indicates a range of their common features such as the continuing and multilevel nature of the professional training system; basic disciplines; similar forms of training organization.

Among different features, we can distinguishoriginal approaches to developing curricula and syllabi, outlining theoretical and practical components of training, allocatingacademic hours to student workload and independent work, organizingplacements, choosing specialization and optionl courses.

Prospects for further studies we see in creating and testing a handbook for future teachers in order to improve their legal training.

\section{REFERENCES}

1. Arkhangelskii, S. I. (1980). Uchebnyi protcess $v$ vysshei shkole $i$ ego zakonomernye osnovy i metody. Moskva: Vysshaia shkola.

2. Venttcel, K. N. (1918). Otdelenie shkoly ot gosudarstva i Deklaratciia prav rebenka. Moskva.

3. Eremkin, A. I. (1984). Sistema mezhpredmetnykh sviazei v vysshei shkole: Aspekt podgotovki uchitelia. Kharkov: Vysshaia shkola.

4. Ermolich, S. Ia. (2013). Formirovanie pravovoi kultury budushchikh pedagogov $v$ sovremennom obshchestve. Vziato shttp://elib.bspu.by/bitstream/doc/516/1/ АПО12.pdf

5. Dyzhova, A. A. (2012). Povedencheskie aspekty pravovoi kultury molodezhi. Nauchnye trudy prepodavatelei gumanitarnykh distciplin. Istoriia, filosofiia, politika, pravo, $2,42-50$.

6. Mukushev, B., Malibekova, M., \&Mukushev, S. (2009). Modernizatciia soderzhaniia pravovogo obrazovaniia v pedagogicheskom vuze. Alma Mater: Vestnik vysshei shkoly, 9, 46-50.

7. Mukushev, S. (2009). Osnovnye napravleniia razvitiia pravovogo obrazovaniia v pedagogicheskikh vuzakh Respubliki Kazakhstan. Vziato shttp://naukarus.com/osnovnyenapravleniya-razvitiya-pravovogo-obrazovaniya-v-pedagogicheskih-vuzah-respublikikazahstan. 
8. Tcarik, I. (2008). Formirovanie pravovoi kultury shkolnikov v protcesse grazhdanskogo vospitaniia. Obrazovanie cherez vsiu zhizn: nepreryvnoe obrazovanie $v$ interesakh ustoichivogo razvitiia, 6, 333-336.

9. Utiupova, G. E. (2017). Razvitie sistemy podgotovki pedagogicheskikh kadrov Kazakhstana $i$ Germanii (na primere uchitelei nachalnykh klassov). (Diss. d-ra filos). Kazakhskii natcionalnyi pedagogicheskii universitet imeni Abaia, Almaty.

10. Ziaziun, I. (1997).Pedahohichna maisternist. Kyiv: Vyshcha shkola. 